ОСОБЛИВОСТІ РОЗВИТКУ ЯКОСТЕЙ МОВЛЕННЄВОЇ КУЛЬТУРИ

МАЙБУТНІХ ФАХІВЦІВ З ІНФОРМАЦІЙНОЇ, БІБЛІОТЕЧНОЇ TA APXIBHOÏ СПРАВИ

\title{
PECULIARITIES OF DEVELOPMENT OF QUALITIES OF SPEECH CULTURE OF FUTURE PROFESSIONALS IN INFORMATION, LIBRARY AND ARCHIVE BUSINESS
}

У статті досліджено особливості розвитку якостей мовленнєвої культури майбутніх фрахівиів з інформаційної, бібліотечної та архівної справи; обгрунтовано необхідність роботи з розвитку культури мовлення студентів; з'ясовано ефективні шляхи розвитку необхідних якостей культури їхнього мовлення; визначено роль комунікації у профресійній діяльності працівників інфрормаційних відділів, бібліотекарів та архівістів. Актуальність теми цього дослідження зумовлена тим, що провідне місце в процесі підготовки майбутніх працівників інформаційних відділів, бібліотекарів та архівістів посідає розвиток необхідних якостей їхньоі культури мовлення.

Мета статmі - дослідити особливості розвитку якостей мовленнєвої культури майбутніх фрахівців з інформаційної, бібліотечної та архівної справи; обгрунтувати необхідність роботи з розвитку культури мовлення студентів; з'ясувати еорективні шляхи розвитку необхідних якостей культури їхнього мовлення; визначити роль комунікації у профресійній діяльності працівників інфрормаційних відділів, бібліотекарів та архівістів. Щоб забезпечити комунікативну досконалість мовлення, що полягає у правильності, змістовності, логічності, багатстві, точності, виразності, доречності й доцільності викладу, кожний фрахівець з інформаційної, бібліотечної та архівної справи мусить уміло послуговуватися мовними засобами різних рівнів.

Велике значення для розвитку якостей мовленнєвої культури майбутніх працівників інформаційних відділів, бібліотек та архівів має систематичне й цілеспрямоване практикування в мовленні.

Мовлення фрахівців з інфрормаційної, бібліотечної та архівної справи має бути зразком комунікативної діі. Сорормованість культури мовлення є важливим показником загальної культури та професіоналізму працівників інфрормаційних відділів, бібліотек та архівів. Їхнє мовлення має бути правильним, змістовним, логічним, багатим, точним, виразним, доречним та доцільним.

Для отримання результатів дослідження використано загальнотеоретичні та спеціальні методи: описовий, аналізу та синтезу, абстрактно-логічний та ін.

Ключові слова: мовлення, культура мовлення, якості мовленнєвої культури, пра вильність, змістовність, логічність, багат- ство, точність, виразність, доречність доцільність мовлення.

The article investigates the peculiarities of the development of speech culture qualities of future specialists in information, library and archives, the necessity of work on the development of the culture of speech of students is substantiated, the effective ways of development of the necessary qualities of the culture of their speech are determined, the role of communication in the professional activity of employees of information departments, the library is determined and archivists.

The relevance of the topic of this study is due to the fact that an important place in the preparation of future employees of information departments, librarians and archivists is the development of the necessary qualities of their language culture. The purpose of the article is to investigate the peculiarities of development of speech culture qualities of future specialists in information, library and archives, to substantiate the need to work on the development of students' culture of speech, to find out effective ways of developing the necessary qualities of their language culture, to determine the role of communication in the professional activity of employees of information departments, librarians and archivists.

In order to ensure the communicative excellence of speech, which consists in correctness, content, logic, richness, accuracy, expressiveness, relevance and expediency of presentation, every specialist in information, library and archives should be able to use linguistic means at different levels.

Systematic and purposeful practice in speech is essential for developing the qualities of speech culture of future employees of information departments, libraries and archives.

Speech of information, library and archival professionals should be a model of communicative action. The formation of a culture of broadcasting is an important indicator of the general culture and professionalism of employees of information departments, libraries and archives. Their speech must be correct, meaningful, logical, rich, accurate, expressive, relevant and appropriate. To obtain the results of the study used general theoretical and special methods: descriptive, analysis and synthesis, abstract-logical, etc. Key words: speech, culture of speech, quality of speech culture, correctness, content, logic, wealth, accuracy, expressiveness, relevance and expediency of speech. дисциплін та соціальних комунікацій

Мукачівського державного університету
Постановка проблеми. Розвиток якостей мовленнєвої культури майбутніх орахівців з інформаційної, бібліотечної та архівної справи, вдосконалення їхнього професійного мовлення одне з актуальних завдань сучасної вищої школи. Культура мовлення має вагоме значення у налагодженні фрахівцями соціальних, профресій- них контактів, є засобом їх самовираження за допомогою мови і мовлення. Актуальність теми цього дослідження зумовлена тим, що вагоме місце в процесі підготовки майбутніх працівників інорормаційних відділів, бібліотекарів та архівістів посідає розвиток необхідних якостей їхньої культури мовлення. 
Аналіз останніх досліджень і публікацій. Проблема мовленнєвої культури була предметом уваги М. Алефіренка, Н. Бабич, О. Біляєва, І. Дроздової, М. Пентилюк, І. Марунича, І. Гайдаєнко, Л. Струганець, І. Хом'яка та інших дослідників, у працях яких окреслюються якості культури професійного мовлення та звертається увага на типові порушення літературних норм. Вивченню різноманітних питань культури мовлення присвячено низку публікацій $[1 ; 2 ; 3 ; 4 ; 5 ; 6 ; 7 ; 8 ; 9 ; 10]$.

Мета статті - дослідити особливості розвитку якостей мовленнєвої культури майбутніх фрахівців з інорормаційної, бібліотечної та архівної справи; обґрунтувати необхідність роботи з розвитку культури мовлення студентів; з'ясувати ефективні шляхи розвитку необхідних якостей культури їхнього мовлення; визначити роль комунікації у профресійній діяльності працівників інорормаційних відділів, бібліотекарів та архівістів.

Виклад основного матеріалу. Під культурою мовлення розуміється володіння нормами літературної мови у вимові, вживанні слів та їх форм, у будові речень тощо. Культура мовлення віддзеркалює ціннісні орієнтації, гармонію професійних знань, комунікативних і морально-психологічних можливостей, характеризує вихованість особистості, уміння висловлювати думки, дотримуватися етичних норм спілкування. Опанування майбутніми фахівцями з інформаційної, бібліотечної та архівної справи якостей культури мовлення, мовленнєвого етикету $€$ передумовою ефективності їхньої профресійної й особистісної комунікації.

Профресійна сорера працівників інфрормаційних відділів, бібліотекарів та архівістів репрезентує офріційно-діловий і науковий стилі у єдності спільних мовних засобів досягнення комунікативної мети, адже кожний фахівець стикається 3 проблемою підготовки усного публічного виступу чи написання певного документа.

Культуру мовлення фрахівців з інфрормаційної, бібліотечної та архівної справи характеризують такі якості, як правильність, змістовність, логічність, багатство, точність, виразність, доречність і доцільність.

Визначальною якістю культури мовлення є правильність. «Правильність мовлення - це дотримання закріплених у літературній мові норм» [3, с. 47]. Саме за тим, дотримуються чи недотримуються мовці норм, мовлення вважається правильним або неправильним.

Правильність мовлення завжди веде до дотримання норм літературної мови, що діють у мовній системі. Мовні норми - це прийняті в суспільномовленнєвій практиці людей правила вимови, вживання слова, граматичної форми, побудови словосполучення, речення (фрази). Мовні норми характеризуються системністю, історичною і соціальною зумовленістю, стабільністю. Якщо в орфо- епії, граматиці норми орієнтуються на зразок, модель, еталон, то в лексиці реалізація норми підпорядковується ще й змістові, залежить у кожному конкретному випадку від контексту.

Норми літературної мови закріплюють традиції, культурні здобутки минулого і водночас регулюють використання не тільки усталених правил, ай появу нових у процесі мовленнєвої діяльності людей. Нормативним $€$ таке мовлення студентів: 1) що відповідає системі мови; 2) у якому варіант норми володіє новими семантико-стилістичними можливостями, увиразнює, уточнює контекст, дає додаткову і вичерпну інформацію; 3) в якому доречно обґрунтовано застосовані норми з іншого стилю; 4) в якому не допущене змішування норм різних мов під впливом білінгвальної мовленнєвої практики.

Правильне мовлення передбачає користування всіма мовними правилами, уміння будувативисловлювання, що відповідає типу і стилю мовлення.

Змістовність мовлення полягає у глибокому усвідомленні теми та головної думки висловлювання, у докладному ознайомленні 3 наявною інформацією з певної теми, а також у різнобічному й повному розкритті цієї теми.

Істотну якісну рису культури мовлення становить логічність, яка ґрунтується на чіткій семантичній організації висловлень і на послідовності викладу. Недотримання цих умов спричиняє логічну невправність повідомлення.

Багатство мовлення полягає у використанні найрізноманітніших мовних засобів висловлення думок у межах певного стилю. Джерелом багатства мовлення $є$ лексичні, фрразеологічні, словотворчі, граматичні, стилістичні ресурси мови. Для того щоб мовлення було багатим, слід використовувати емоційно-образну лексику, синоніми, фрразеологізми, стійкі вислови тощо.

Критерій точності пов'язаний 3 тим, чи відповідає зміст ужитих мовцем слів прийнятому в літературній мові їх лексичному значенню. Якщо відповідає, то мовлення є точним, не відповідає вважається неточним. «Точність мовлення передбачає, з одного боку, знання і вживання точних значень слів, словосполучень, речень, що відповідають нормам літературної мови, а 3 іншого уміння виражати свої думки так, щоб вони однозначно були сприйняті адресатом мовлення. Вимога точності впливає на добір мовних засобів для побудови усного чи писемного висловлювання.

Відомо, що кожне вжите слово має дві вимоги, як-От:

1) своїм змістом має відповідати предметноречовій дійсності;

2) має бути використане із закріпленим у літературній мові лексичним значенням» [2, с. 141].

Перша вимога, зокрема, полягає у тому, що вжите слово має відповідати тому, що ним номінується. Адже висловлювання втрачає ясність, якщо 
в ньому є слово, яке не співвідноситься 3 наявною в житті реалією.

Другою вимогою $є$ те, що до мовлення необхідно вводити слова з узвичаєним у літературній мові значенням. Це зобов'язує мовця знати насамперед семантику кожного зі слів активного словника.

Мовлення вважається точним, якщо вжиті слова відповідають своїми значеннями смислу висловленої думки. Точність залежить від умінь мовців добирати такі слова, які повністю співвідносяться 3 номінованими предметами, явищами, діями тощо.

Виразність мовлення - якість, яка найбільше залежить від особи мовця, його ерудиції, знання мов, мовленнєвих умінь і навичок. У мові $є$ невичерпні запаси виражальних засобів, які роблять мовлення виразним. Це, зокрема, засоби художнього мовлення і засоби звукового мовлення. Виразність включає в себе й образність мовлення, що передбачає вживання слів і словосполучень у незвичному, метафоричному значенні, а це дає можливість образно, художньо відтворювати дійсність. Тому виражальні засоби можуть бути образними й необразними. Це залежить від стилю висловлювання. Виразність мовлення досягається за таких умов, як: самостійність мислення мовця; інтерес мовця до того, про що він говорить чи пише; належне знання мови і виражальних засобів; досконале володіння стилями мовлення тощо.

Важливими якостями мовлення є доречність та доцільність. У мовленні студентів бувають випадки, коли добір мовних засобів не відповідає меті й умовам спілкування, темі висловлювання, логічному змісту, емоційному забарвленню. Це свідчить про те, що відсутня комунікативна доречність мовлення. Комунікативну доречність визначає мотивований вибір мовних засобів: який із них залежно від мовленнєвої ситуації доречніший, точніший, виразніший. Залежно від різних умов і мети спілкування доречність мовлення буває контекстуальною, ситуаційною, стильовою і психологічно зумовленою. Контекстуальна доречність виявляється в єдності змісту і форми висловлювання. Вона впливає на порядок слів у реченні, а речень - у тексті. Ситуаційна доречність організовує мовлення майбутніх фрахівців 3 інфрормаційної, бібліотечної та архівної справи відповідно до ситуації спілкування. Саме цим зумовлено використання монологу, діалогу, внутрішнього монологу, різних фрорм звертання. Від ситуації залежить темп і тональність мовлення, вибір слова. Важливою є стильова доречність. Адже кожний стиль будується на виборі мовних засобів, їх співвідносності. Тому доречність - важлива ознака кожного стилю мовлення. За нашими спостереженнями відчуття доречності, майстерність змінювати характер мовлення від ситуацій і завдань спілкування виховується мовленнєвою практикою. Доцільність залежить насамперед від того, наскільки повно й глибоко людина оцінює ситуацію спілкування, інтереси, стан адресата.

щоб забезпечити комунікативну досконалість мовлення, що полягає у правильності, змістовності, логічності, багатстві, точності, виразності, доречності й доцільності викладу, кожний фрахівець 3 інфрормаційної, бібліотечної та архівної справи має вміло послуговуватися мовними засобами різних рівнів. 3 цією метою студентам слід навчитися аналізувати тексти різних стилів (офіційно-ділового, художнього, публіцистичного, наукового, розмовного, конфесійного та епістолярного) на лексичному, лексико-семантичному, стилістичному й граматичному рівнях, редагувати, скорочувати тексти, конструювати елементи висловлювання з урахуванням запропонованої мовленнєвої ситуації тощо.

Велике значення для розвитку якостей мовленнєвої культури майбутніх фрахівців 3 інфрормаційної, бібліотечної та архівної справи має систематичне й цілеспрямоване практикування в мовленні. Адже вміння і навички досконалого фахового мовлення виробляються лише в процесі мовленнєвої діяльності.

Правильно підібрані тексти допоможуть сорормувати в студентів уміння правильно складати спочатку вторинні тексти, зокрема конспекти та анотації. Укладаючи конспекти, студенти починають розуміти структуру наукового тексту та особливості його будови. Вони починають також усвідомлювати необхідність написання плану, правильного скорочування слів, тексту. Конспект слугує для збереження основного змісту тексту. У ньому репрезентуються думки автора, а найбільш суттєві висловлювання фріксуються із зазначенням сторінок у тексті-оригіналі. Мета конспекту - глибоко осмислити інформацію, подати її стисло та в зручній для подальшого використання письмовій формі. Написання конспекту зосереджує увагу студентів на головному. Не сприйнявши матеріал, не розуміючи прочитаного, почутого, неможливо виділити і записати основну думку. Під час конспектування слід звертати увагу на виокремлення опорних слів, які мають найбільше смислове навантаження. Вибір студентами ключових висловлювань конспектованих текстів залежить від мети й завдань конспектування. Вміння законспектувати найважливіші інформаційні центри певного тексту значною мірою залежать від глибини його розуміння, власних знань у визначеній галузі тощо.

Анотування - це процес аналітично-синтетичного опрацювання інорормації, метою якого є отримання узагальненої характеристики певного документа, що розкриває його логічну структуру й зміст. Анотації широко використовуються в інфрормаційній та бібліографічній діяльності. Як відомо, анотації виконують дві основні фрункції: сигнальну та пошукову. Сигнальна фрункція полягає у тому, 
що в анотації подається важлива інформація про документ, яка дає можливість встановити його основний зміст та призначення. Пошукова фрункція полягає в тому, що анотація використовується для пошуку конкретних документів й розміщується в інфрормаційно-пошукових системах.

Анотації інорормують користувачів про літературні джерела певного змісту й характеру. Вони дають змогу користувачам скласти достатнє й об'єктивне попереднє уявлення про незнайому для них публікацію та сприяють у пошуку, відборі та систематизації необхідної інформації. Анотації бувають довідковими та рекомендаційними. Довідкові анотації уточнюють заголовок і повідомляють відомості про автора, зміст і жанр документа тощо. Рекомендаційні анотації покликані активно пропагувати, зацікавлювати, переконувати в доцільності прочитання документа. У них $є$ дидактична спрямованість, методичні поради, педагогічні рекомендації. За обсягом рекомендаційні анотації ширші, ніж довідкові.

Анотації розрізняють описові й реферативні. Описові анотації узагальнено характеризують зміст документа та подають перелік основних тем, які в ньому відображені. Реферативні анотації не тільки подають перелік основних тем, а й розкривають їх зміст.

Тексти анотацій мають бути лаконічними, з високим рівнем узагальнення інорормації. У них не доцільно використовувати складні синтаксичні конструкції, які перешкоджають сприйняттю тексту.

Мовлення фрахівців з інфрормаційної, бібліотечної та архівної справи має бути зразком комунікативної дії. Сфрормованість культури мовлення $€$ важливим показником загальної культури та професіоналізму працівників інфрормаційних відділів, бібліотек та архівів. Їхнє мовлення має бути правильним, змістовним, логічним, багатим, точним, виразним, доречним та доцільним. Відомо, що висловити свою думку ясно, зрозуміло, до того ж зацікавити співбесідника розповіддю, переказуванням прочитаного, доведенням своїх позицій нелегко. Важливо дбати про умілий добір слів, завдяки яким передаються відтінки понять, зокрема доречно вживати різноманітні вдалі синоніми. А повторення одних і тих самих чи однокореневих слів за можливості заміни одного 3 них синонімом має розцінюватися як бідність лексичного запасу мовця, що свідчить про відсутність мовленнєвої майстерності.

Майбутнім фрахівцям з інформаційної, бібліотечної та архівної справи слід урізноманітнювати власний словниковий запас. Мовленнєва майстерність виявляється також у різноманітності синтаксичних конструкцій, експресивних описових зворотів.

Висновки. Розвиток якостей мовленнєвої культури майбутніх фрахівців з інформаційної, бібліо- течної та архівної справи є невід'ємною частиною їхньої профресійної підготовки, органічною потребою розвитку працівників галузі культури і мистецтва. Досконалим мовлення визнається в тому разі, коли воно відповідає всім якостям культури мовлення. Уміння і навички досконалого мовлення виробляються лише в процесі мовленнєвої діяльності, тому велике значення для розвитку якостей мовленнєвої культури майбутніх працівників інфрормаційних відділів, бібліотек та архівів має систематичне й цілеспрямоване практикування в мовленні. Перспективу подальших досліджень вбачаємо у вивченні найбільш поширених помилок студентів у писемному мовленні та визначенні найефективніших шляхів їх подолання.

\section{БІБЛІОГРАФІЧНИЙ СПИСОК:}

1. Бабич Н.Д. Основи культури мовлення. Львів : Світ, 1994. 232 с.

2. Гудачок Г.Ю. Точність мовлення як важливий критерій комунікативної компетентності вчителя початкових класів / Г.Ю. Гудачок, Н.Ф. Попович. Освіта $і$ формування конкурентоспроможності фрахівців в умовах євроінтеграції : збірник тез доповідей III Міжнародної науково-практичної конференції, 24-25 жовтня 2019 р., Мукачеве / Ред. кол.: Т.Д. Щербан (гол. ред.) та ін. Мукачеве : Вид-во МдУ, 2019. С. 141-143.

3. Дорошенко C.I. Основи культури і техніки усного мовлення. 2-е вид., перероб. і доп. Харків : «OBC», 2002. 144 c.

4. Загнітко А.П. Основи мовленнєвої діяльності / А.П. Загнітко, І.Р. Домрачева. Донецьк : Український культурологічний центр, 2001. 461 с.

5. Мацько Л.І. Культура української мови / Л.І. Мацько, Л.В. Кравець. Київ : Академія, 2007. 360 с.

6. Мацько Л.І. Стилістика української мови / Л.І. Мацько, О.М. Сидоренко, О.М. Мацько. Київ : Вища школа, 2003. 411 с.

7. Моргун А.В. Правильність як головна якість культури мовлення фрахівців 3 інфрормаційної, бібліотечної та архівної справи / А.В. Моргун, Н.Ф. Попович. Актуальні проблеми навчання $і$ виховання в умовах інтеграційних процесів в освітньому та науковому просторах : збірник тез доповідей II Bсеукраїнської науково-практичної інтернет-конференції, 07 листопада 2019 р., Мукачеве. Мукачеве : МДУ, 2019. С. $280-282$.

8. Пасинок В.Г. Основи культури мовлення. Київ : Центр навчальної літератури, 2012. 184 с.

9. Пентилюк М.І. Культура мови і стилістика. Київ : Освіта, 1994. 268 с.

10.Прокопович Л.С. Якості культури усного мовлення фрахівців 3 інфрормаційної, бібліотечної та архівної справи / Л.С. Прокопович, Н.Ф. Попович, Л.С. Нефьодова. Актуальні проблеми навчання $i$ виховання в умовах інтеграційних процесів в освітньому та науковому просторах : збірник тез доповідей II Всеукраїнської науково-практичної інтернет-конференції, 07 листопада 2019 р., Мукачеве. Мукачеве : МДУ, 2019. С. 301-304. 